\title{
Resource Scarcity and Degradation and Farm Household Circumstances in the Northwestern Highland Ethiopia: A Case Study in the Chemoga Watershed ${ }^{1}$
}

\author{
Woldeamlak Bewket ${ }^{2}$ and Leo Stroosnijder ${ }^{3}$
}

\begin{abstract}
In Ethiopia, like in the other agriculture-based poor countries, there is a heavy dependence on the land resource for livelihood. This dependence has been leading to degradation of the resource base, which impoverishes the population. Poverty and resource depletion are highly intertwined in the country, reinforcing each other in a vicious circle. This paper reports results of a survey of smallholder farmers' circumstances in relation to the status of the land resource in a typical watershed (the Chemoga watershed) in the northwestern highlands of Ethiopia. The study reveals that the people are poor, living on average annual incomes ranging from Birr 779 to 1692 (1.00 birr $\sim 0.125$ \$US) per household which has 6.3 members on average. Land and livestock are the bases of livelihood for the people. Only very few households were found to be engaged in off-farm activities as additional sources of income.

On the other hand, land has become scarce because of the increasing population. As witnessed by the surveyed households, landholdings per household have been declining; and productivity of croplands has declined over time. Likewise, there has been a decreasing trend in the number of livestock owned per household, while the total livestock population of the communities has increased and caused overgrazing and feed shortages, and necessitated the use of crop residues as livestock feed rather than soil conditioner. These negative trends in resource availability, while the population is increasing, suggest that the future is bleak. Hence, interventions that integrate development and conservation measures based on local-scale biophysical and socioeconomic realities are urgently needed. Generally, solutions should include improving productivity of the farming system through technical interventions, creating non-farm employment opportunities to the population and easing human and livestock population pressures on the land.
\end{abstract}

${ }^{1}$ The fieldwork was financially supported by AAU/ISS/SAIL project titled: 'Capacity Building for Training and Policy Research in Regional and Local Development Studies in Ethiopia'. We extend sincere thanks to all the farmers and the enumerators who took part in the survey. We would like also to acknowledge the two anonymous reviewers for their critical comments and valuable suggestions.

${ }^{2}$ Depariment of Geography \& Environmental Studies, Addis Ababa University, Addis Ababa, Ethiopia. E-mail: wbewket@geog.aau.edu.et

${ }^{3}$ Department of Environmental Sciences, Erosion and Soil \& Water Conservation Group, Wageningen University, Wageningen, The Netherlands. E-mail: L.Stroonijder@wur.nl 


\section{Introduction}

Resource degradation associated with modalities of their use for agriculture has become a serious problem common to most developing countries. The mounting demographic pressure coupled with slow technical changes in the sector has placed substantial stress on the resource base. In consequence, devegetation, expansion of cultivation into ecologically marginal areas, soil degradation, alteration of hydrologic regimes, disturbance of local and/ or regional climates, depletion of biodiversity and expansions of desert-like conditions have become environmental trends. These environmental trends, in turn, are leading to persistent declines in the productive capacities of the resources, allowing food deficits to follow growing trends and compelling the populations to live with decreasing opportunities and worsening situations.

Ethiopia is one of those countries characterized by such negative environmental trends occasioned by the heavy dependence on the land for livelihood. The population pressure on the land is evident from the disproportionately high contribution of the agricultural sector. It employs about $80 \%$ of the labor force, contributes some $50 \%$ of the GDP and accounts for $85 \%$ of the total foreign exchange earnings, in any single year (FDRE 1997; Berhanu and Seid 1999). On the other hand, the sector is presently unable to feed the national population. Food production lingers behind the growth of population. As a study indicated, between 1980 and 1997, for instance, the population of the country grew at the rate of about 3\% per annum while cereal crops production grew by only $0.9 \%$ per annum (Mulat 1999). This means that per capita food availability has been falling and poverty worsening. The country has become one of the major food aid recipients in Africa. As Clay et al. (1999) reported, over the 1985-1996 decade, annual cereal food aid ranged from 200,000 to 1.2 million metric tones, which meant $3.5 \%$ and $26 \%$ of the total national production, respectively. Resource degradation is identified to be one of the major reasons for the distressing trend in food production (TGE 1992, Sutcliffe 1993; Bekele and Holden 1999).

Of the different forms of resource degradation, soil erosion by water is the most pressing (Hurni 1993; Sonneveld 2002). According to Hurni (1993), average soil loss rates on arable lands is $42 \mathrm{t} / \mathrm{ha} / \mathrm{year}$, which by far exceeds the rate of soil formation. By the mid 1980s, FAO (1986) estimated that erosion reduces national food production levels by $1-2 \%$ per annum, while the associated declines in humus contents of the soils leads to a further annual decline by 1 per cent. The traditional practice of fallowing for soil improvement is largely abandoned because of high man-land ratios. The shortage of fuel wood has necessitated the use of manure as source of energy rather than soil conditioner (Woldeamlak 2003). Similarly, crop 
residues are needed as . ad for livestock, sources of energy and some as covers for roof making them too scarce to be used for soil fertility replenishment (Woldeamlak 2001). On the other hand, use of artificial fertilizers and other factor inputs that will improve productivity such as improved seeds, herbicides and pesticides is very low and, in deed, are beyond the reach of the majority of Ethiopian farmers (Alemneh 2003). The outcome has thus been inexorable loss of land productivity and growth of food insecurity, and emanation of conditions for more household as well as national level food insufficiency and insecurity.

Agricuiture being the foundation, improvement in this sector is the key to Ethiopia's food security and overall economic development. In recognition to this, the existing economic development strategy of the country identifies agriculture as 'the lead growth sector', and the overall economic development approach is Agricultural Development Led Industrialization (ADLI) (TGE 1991). The success of the ADLI depends, among other things, on the conservation-based use of the natural resources base. Planning for effective and sustainable resource conservation, in turn, requires a detailed analysis and understanding of physical environmental settings at local level as these shape socioeconomic systems, and socioeconomic circumstances of smallholder farmers, the sector contributing the buik of the national crop and livestock outputs.

Given the diversity in the physical and socioeconomic environments and the spatial variations in the type and severity of resource degradation in Ethiopia, conservation and development interventions ought to be site-specific. For instance, lack of consideration of local level physical environmental and socioeconomic factors and pursuit of a top-down approach were the major factors that led to failure of the soil and water conservation efforts of the Derg regime (Azene 1997, 2001).

The aim of this study is to make a modest contribution to the much needed but very scarce local level information on scarcity and degradation of resources and farmers' circumstances in rural Ethiopia. It describes socioeconomic circumstances of smallholder farmers in relation to the physical environmental setting and status and dynamics of natural resources in a typical watershed (the Chemoga watershed) in the northwestern highlands. Even though the study is site-specific and the empirical findings reveal the reality in the case study site, the facts, analyses and conclusions generally unveil the conditions in much of highland Ethiopia. Thus recommendations given on necessary measures that ought to be taken to promote sustainable resource use and development have a wider relevance. However, we acknowledge that the study does not attempt to cover the various sociocultural and institutional factors that have implications on socioeconomic circumstances of farm households. 
The following section (section 2) presents theoretical context for the paper, section 3 describes data and methods of the study, section 4 describes the physical environmental setting of the study watershed, and section 5 discusses farm household circumstances in the watershed with reference to scarcity and degradation of the land resource. Section 6 concludes the study with some policy recommendations.

\section{Population, Poverty and Environment: Theoretical Context}

The nexus between population growth, economic development and environment is one of the most widely debated issues over several years. The emphasis has been on agricultural production in rural settings of developing countries. Volumes of publications have been produced on the subject, but there is no consensus as yet regarding the nature of relationships between population growth, environmental changes and poverty (Martine 1996). Generally, much of the literature on the implications of population growth for environmental changes can be categorized into either of the catastrophic or optimistic theoretical perspectives, represented respectively by the Malthusian (after Malthus 1798) and the Boserupian (after Boserup 1965) schools of thought. Proponents of each school of thought argue with their own theoretical and ideological underpinnings as well as empirical evidences from elsewhere. According to Martine (1996), the intensity of the debate between these two opposing camps has been shedding "more heat than light".

Rapid population growth, according to the Malthusian theory, has the potential to overtake agricultural production and economic growth, and presents a threat to the physical environment. Adherents of this theory, the majority of whom are ecologists by training, argue that population growth inevitably leads to scarcity of agricultural lands, farmland fragmentation, overcultivation, soil erosion, deforestation, loss of biodiversity and a general deterioration in the productive capacity of the land resource, or environmental degradation (Hardin 1993; Myers and Simon 1994; Goodland 1992; Brown 1995; Ehrlich and Ehrlich 1990). The ultimate effect of environmental degradation is believed to be poverty of people. As a logical derivation of their argument, population growth is, for proponents of the Malthusian theory, a critical problem that needs to be tackled at all costs.

In line with the Malthusian theory, UNICEF (1994) introduced the concept of population-poverty-environment (PPE) spiral. According to this report, high population growth, poverty and environmental degradation are feeding on each other and resulting in a downward PPE spiral in the underdeveloped world. These three problems are so intertwined that they should be regarded as one integral 
problem (UNICEF 1994). Figure 1 schematically shows the interrelationships between population, poverty and environment as presented by UNICEF (1994).

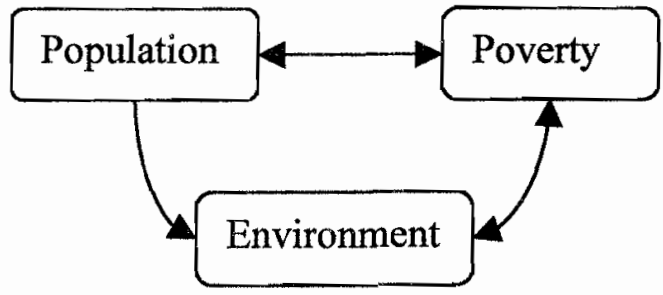

Figure 1. The population-poverty-environment nexus

As shown in the figure, there is a reciprocal interaction between population growth and poverty. Population growth, particularly where it is faster than economic growth, increases unemployment, lowers wages and increases landlessness in the agricultural sector. It also creates a heavy strain on such social services as schools and health centers. All these conditions lead to increased poverty. Poverty, in turn, reiniorces rapid population growth for many reasons. First, in poor countries, children are needed for household labour requirements and as old-age security because of the absence of social security programs. Second, poverty leads to high death rates among children. This persuades families to have as many children as possible to compensate for any loss. Third, poverty is strongly related with poor education and illiteracy, especially among girls, which implies low level of awareness of family planning services, low status of women and their disempowerment for decision-making over the desired number of children.

Population growth is also expected to have adverse impacts on the environment. Population growth means, in the absence of alternative sources of livelihood, increasing pressure on the land resource. The increasing pressure on the land resource will then lead to deforestation, overgrazing, soil erosion, water pollution and similar environmental problems.

Finally, a two-way interaction is depicted between poverty and environmental degradation (Fig. 1). Poverty contributes to environmental degradation because it dictates the poor to pursue short-term survival strategies at the expense of longterm stewardship for the environment. In other words, poverty increases discount rates of the poor and thus decreases incentives to conserve resources for future use. Poor people will also have limited access, if any, to technologies to mitigate environmental damages. Environmental degradation, in turn, exacerbates the level of poverty. It leads to declining per capita agricultural yields, availability of forest, 
water and rangeland resources. And, according to UNICEF (1994), the poorer segments of society will be disproportionately affected by environmental degradation.

The opposing theory (Boserupian theory), on the other hand, argues that population growth rather enhances, instead of being a hurdle, economic and technological development (Boserup 1965, 1981; Simon 1981 1990). In view of this theory, population growth is a source of increased efficiency, economies of scale and technological innovation that not only expands the limits of carrying capacity of the environment, but also improves living standards of the people and environmental conditions. Hence, it is argued, "there is no environmental justification for intervention to control population growth'.

There are also a fairly large number of research reports that lie separate from the catastrophic and optimistic perspectives and argue that economic development and environmental degradation are largely independent of population growth (Panayotou 1993, 1994; Eberstadt 1995; Tiffen et al. 1994; Mazzucato and Niemeijer 2000). In this view, population growth is not necessarily a stimulus for innovation, agricultural intensification and environmental conservation, but also it does not necessarily have a negative impact on economic development and the environment. In the Machakos district of Kenya, for instance, Tiffen et al. (1994) reported that population growth was accompanied by improvements in environmental conditions and local livelihoods, because of such enabling conditions as favorable property rights regimes, product markets and strategies adopted by the small farmers. As it is argued, the effect of population growth largely depends on whether or not sound agricultural and resource use practices are employed (Leach and Mearns 1996; Scherr 2000). If the later is the case, increasing population can sustain or even stimulate environmental improvements (Leach and Mearns 1996), as people can be agents of environmental restoration, improvement and management (Gracia-Barrios and Gracia-Barrios 1990).

In Ethiopia, many researchers agree that the PPE downward spiral is the prevailing state (Grepperud 1996; Bekele and Holden 1998; Belay 2000; Sonneveld 2002; Ermias 2003; Sahilu 2003). According to Sahilu (2003), the Ethiopian population grew from around 11.8 million in 1900 to 24 million in 1960 and to more than 70 million presently, some three-fold increase over a period of four decades. Currently the population is growing with a rate of nearly $3 \%$ per annum, and with this rate of increase it is doubling roughly every 23 years. On the other hand, there is no matching growth in the economy and the overwhelming majority of the growing population remains directly dependent on the natural environment for livelihood. As a result, according to Sahilu (2003), population growth is undoubtedly a major cause of environmental degradation especially in 
the highlands where the pressure is at its highest. Ermias (2003) concludes that "every new birth means a new mouth to feed, an additional bundle of fuel wood to cook the food with, and a new body to clothe and house" and as such population growth is an underlying cause of environmental degradation in Ethiopia. There are only few studies that argue that population growth is not the single most important factor of environmental degradation in the country (Muluneh 2003). In his study in West Gurageland, Muluneh (2003) discovered that non-demographic factors have also contributed strongly to the observed environmental dynamics.

\section{Data and Methods}

\subsection{Biophysical Data}

The study area, the Chemoga watershed, lies within $10^{\circ} 18^{\prime} \mathrm{N}$ to $10^{\circ} 39^{\prime} \mathrm{N}$ and $37^{\circ} 44^{\prime} \mathrm{E}$ to $37^{\circ} 53^{\prime} \mathrm{E}$. In administrative terms, it is located in Gozamen woreda (district), East Gojjam administrative zone, Amhara Regional State (Fig. 2). Situated some $300 \mathrm{~km}$ northwest of Addis Ababa, the watershed forms part of the northwestern highlands of Ethiopia. With a total area of $364 \mathrm{~km}^{2}$, it is inhabited by a total population of roughly 40,768 , as estimated from the rural population density (112 persons/ $\mathrm{km}^{2}$ ) of the Gozamen woreda (Gozamen Woreda Office of Agriculture 2001). The watershed is from amongst the headstreams of the Blue Nile. The Blue Nile basin is presentiy significantly degraded and is following a trend of environmental deterioration (El-Swaify and Hurni 1996; Mengistu 1997). The Chemoga watershed is part of this degraded and degrading basin, which will be representative of the conditions in large parts of the temperate (locally known as dega) and alpine (locally known as wurch) climatic and agro-ecological belts of the northwestern highlands.

The biophysical attributes of the watershed described in this paper include physiography, soils, agroclimatic conditions and land use and land cover. Obviously, these biophysical elements of the watershed constitute part of the natural capital in the livelihood assets of the local people. They affect livelihood outcomes of the local people directly or indirectly. The data about these environmental variables were collected from various sources. Published materials and topographic and thematic maps of the area provided data about the geology, physiography and soils. For the analysis and description of the agroclimatic condition of the area, meteorological data collected from the National Meteorological Services Agency (NMSA) of Ethiopia were used. The land cover/ 
use data were obtained from a thematic study of land cover/ use dynamics in the watershed conducted by the author previously.

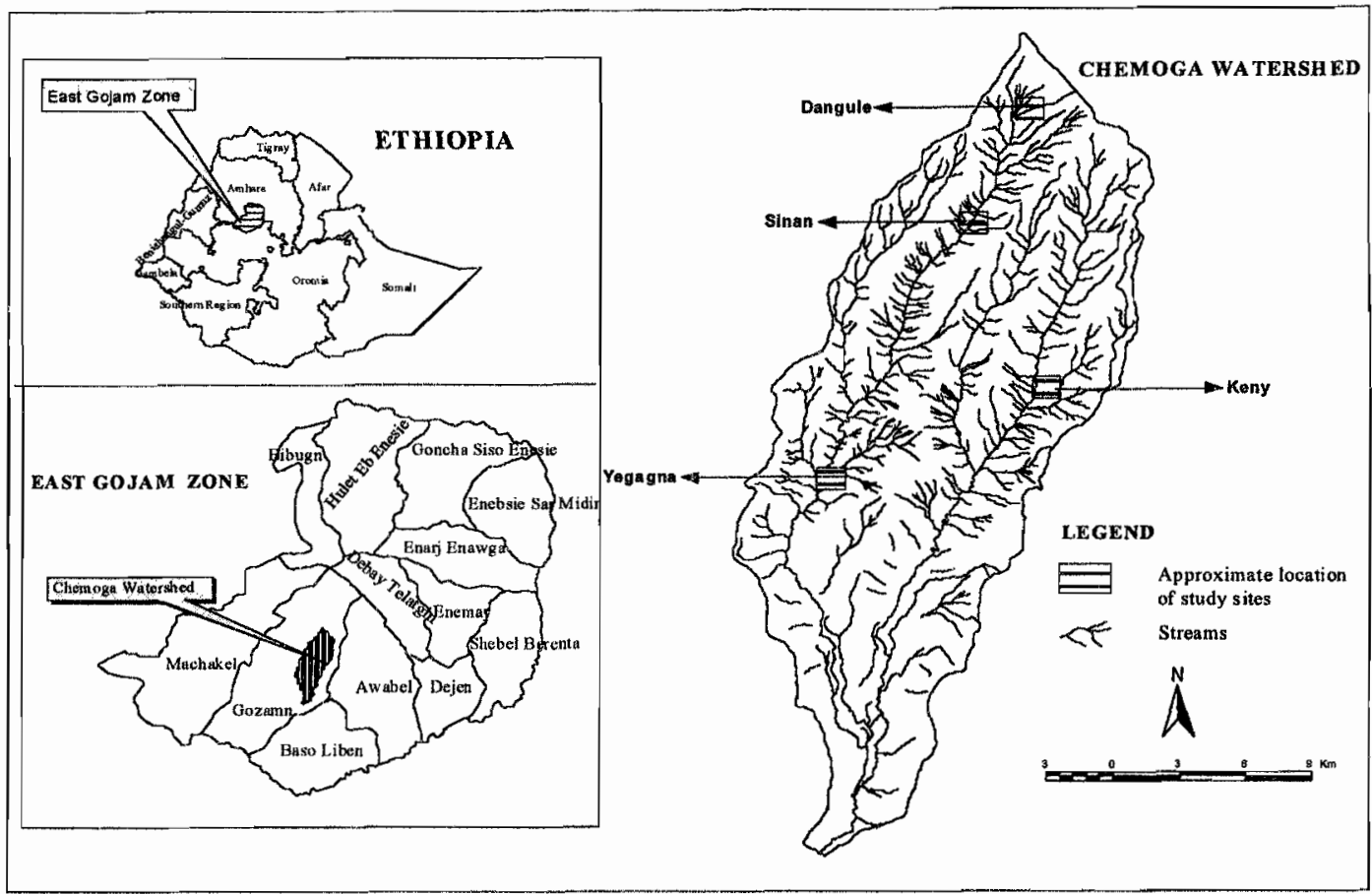

Figure 2. Location map of the study area

\subsection{Socio-economic Data}

The socioeconomic data required for study came from a structured household survey conducted between March and May 2000. The procedure of the survey was as follows. First, four sample villages, the lowest tiers in the administrative structuring of Ethiopia, were selected on purpose to cover the upstream, midstream and downstream reaches of the study watershed (Table 1). Then, lists of households in each of the villages were obtained from the respective village administrations. With the lists, a systematic random sampling procedure was used to select a total of 133 sample households. In cases where a selected household head happened to be away from home for a long time or was unwilling to be interviewed, a randomly selected substitute was included. Given the relative 
homogeneity of the subsistence farmers in the four villages in terms of physical environmental factors and resource endowments, the sample size of each village would be reasonably representative of the population it stood for.

Table 1. The study villages in the Chemoga watershed

\begin{tabular}{|l|l|l|l|l|c|}
\hline Village & $\begin{array}{l}\text { Position in the } \\
\text { watershed }\end{array}$ & $\begin{array}{l}\text { General } \\
\text { elevation }(\mathrm{m})\end{array}$ & $\begin{array}{l}\text { Climatic } \\
\text { zone }\end{array}$ & $\begin{array}{l}\text { Total No. of } \\
\text { households }\end{array}$ & $\begin{array}{l}\text { Sample } \\
\text { size }\end{array}$ \\
\hline Dangule & Upstream & $3200-3800$ & Alpine & 1121 & 38 \\
\hline Sinan & Upstream & $2800-3200$ & Temperate & 868 & 31 \\
\hline Keny & Midstream & $2600-3000$ & Temperate & 909 & 32 \\
\hline Yegagna & Downstream & $2450-2600$ & Temperate & 772 & 32 \\
\hline
\end{tabular}

The survey questionnaires were comprised of both closed- and open-ended types of questions and covered various issues: household demographic composition, landholding, crop production and livestock tending, off-farm employment, income from sale of wood and trees, household expenditures, and various issues on resource scarcity and degradation. The researcher and four enumerators, all of whom speak the local language, conducted the interview. The enumerators were first trained by the researcher about how to present and explain the questions to the respondents. They were also advised to inform each respondent of the purpose of the survey before starting the interview. The interviews were conducted by going to each interviewee's homestead. The time taken by an interview ranged between 60 and 90 minutes. Early mornings and late afternoons were convenient times for the interviewees. Attempt was also made to crosscheck responses of the farmers on such questions as landholding sizes and number of livestock owned from records of the village administration, as farmers sometimes understate these fearing that land use fees and other government obligations might be increased. In addition to the formal questionnaire survey, informal discussions were also held with some farmers to generate additional information on the issues covered by the structured questionnaire.

The data generated by the structured questionnaires were analyzed using the frequencies and descriptive procedures of the SPSS release 10 (Bryman and Cramer 2001). The qualitative data generated by informal discussions with the local people were used to substantiate the quantitative results from the structured questionnaires. 


\section{The physical environmental setting of the Chemoga watershed}

\subsection{Geology, Physiography and Soils}

Geologically, the Chemoga watershed is part of the Ethiopian highlands that largely owe their altitude to the uplift of the Arabo-Ethiopian landmass and the subsequent outpouring of basaltic lava flows during the Tertiary period (Mohr 1971). Thus, the surface geology is of basaltic rocks, which are the parent materials for the overlying soils (Mohr 1971). The physiography of the watershed reflects its geologic history. The uplift created an elevated landmass, and the subsequent lava emission provided a thick protective cap and added to the elevation. This landscape has been subjected to geomorphic processes that have significantly reshaped it. Currently, the Chemoga watershed is characterized by diverse topographic conditions. The elevation ranges from 2420 to nearly $4000 \mathrm{~m}$. A mountainous and highly dissected terrain with very steep slopes characterizes the upstream part of the watershed; and an undulating topography and gentle slopes characterize the downstream part. The area distribution of the watershed grouped by slope classes is given in Table 2. A substantial percentage $(\sim 40 \%)$ of the total area has a general slope of more than $15 \%$, which may be described as moderately steep and above.

Table 2. Slope class distribution in Chemoga watershed

\begin{tabular}{|l|l|l|l|}
\hline Slope class (\%) & Area $\left(\mathrm{km}^{2}\right)$ & $\%$ of total area & Description \\
\hline$<2$ & 122.8 & 33.7 & Flat or almost flat \\
\hline $2-8$ & 38.1 & 10.5 & Gently sloping \\
\hline $8-15$ & 57.4 & 15.8 & Sloping \\
\hline $15-30$ & 103.9 & 28.5 & Moderately steep \\
\hline $30-55$ & 32.4 & 8.9 & Steep \\
\hline$>55$ & 9.4 & 2.6 & Very steep \\
\hline Total & 364.0 & 100.0 & - \\
\hline
\end{tabular}

Physiography can create both opportunities and constraints to development. In the study watershed, the higher elevation may influence air movement and contribute to the occurrence of higher orographic rainfall. The elevation gradient and the associated climatic conditions allow cultivation of a wider range of crops and the high altitude offers a favorable environment for human habitation which is free from tropical pathogens. On the other hand, the irregular surface created by frequent and deep dissection constitutes a major barrier to communication and impedes, one way or another, agricultural and infrastructure development. Also, the 
steep slopes and rugged terrain constitute natural hazards with respect to soil erosion. Under such physiographic conditions, even rains of moderate intensity suffice to cause massive erosion and making soils shallower and stony.

The soils in the watershed that cover much of the total area can be classified into three types on the basis of their color: dark brown, reddish and grayish (gray to dark). The dark brown soils belong to the Andosols soil associations, the reddish soils belong to the Nitisols and the grayish soils belong to the Fluvisols according to the FAO/Unesco (1990) soil classification system. The dark brown soils are at high altitudes with a temperate- and alpine-like climate. They have developed from the volcanic ash deposit, and cover a large area in the upstream part of the watershed. The reddish soils occur on nearly level to gently undulating land that is well drained. They are derived from complete decomposition of the volcanic lava flows by deep tropical weathering in situ. These soils largely occupy the midstream and downstream parts of the watershed. The grayish (gray to dark) soils occur in the flood plains in the downstream reaches of the watershed, where sedimentation occurs every wet season. These are deep soils that have developed from sediments washed down from upstream areas.

\subsection{Agro-climatic Condition}

According to the simplified traditional agroclimatic classification system, which considers only temperature and altitude, the Chemoga watershed lies within dega (temperate) and wurch (alpine) zones. The climatic condition is generally humid. As measured at Debre-Markos $\left(10^{\circ} 20^{\prime} \mathrm{N} \& 37^{\circ} 40^{\prime} \mathrm{E}\right.$ and elevation 2411 masl), mean annual temperature is $14.5^{\circ} \mathrm{C}$ with a range from $13.2^{\circ} \mathrm{C}$ in July and August to $17.3^{\circ} \mathrm{c}$ in March. Average annual total rainfall is $1300 \mathrm{~mm}$. The rainfall pattern is unimodal with a rising limb starting in May and reaching to a peak between July and August. More than $75 \%$ of the total rain falls in the four months of June to September (locally known as kiremt season) (Fig. 3). The dry months are from November to February (locally known as bega season), when less than $5 \%$ of the annual total rainfall occurs. Since the watershed lies at a higher elevation than Debre-Markos, temperatures must be lower and rainfall probably higher than these values.

Average annual total potential evapotranspiration (PET), as estimated by the Thornthwaite's method (Thornthwaite 1948), is $855.7 \mathrm{~mm}$. It reaches a peak in March, matching with the temperature pattern, but generally with a very low monthly variation. The monthly rainfall exceeds the calculated PET only in the months of June to September. In the rest of the months, PET exceeds the rainfall. 
The uneven distribution of the rainfall gives rise to a serious shortage of water during the dry season in some parts of the watershed.

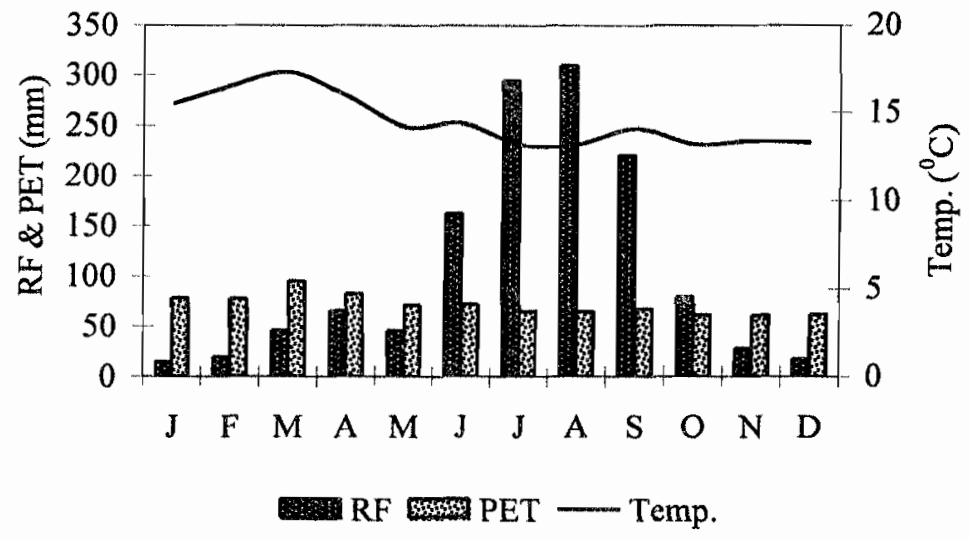

Figure 3. Mean monthly rainfall (RF), potential evapotranspiration (PET) and temperature (Temp.).

\subsection{Land Cover/Use}

The land cover/use pattern in the watershed is shown in Table 3. A detailed discussion of land cover/ use patterns and temporal changes and its environmental implications is presented in Woldeamlak (2002). Only a brief note is given here. The largest proportion of the watershed is under farm \& settlement use $67 \%$ of total area), distantly followed by the marshland and woodlands. There is a pond amid the marshland, occupying roughly 40 ha. Generally, land areas under vegetative covers are small; and that under natural vegetation has been decreasing. This has implications on runoff production, soil erosion and land degradation. 
Table 3. Land cover/ use pattern in the Chemoga watershed, 1998.

\begin{tabular}{|l|l|l|}
\hline Land cover/use & Area (ha) & \% of total area \\
\hline Forest & 1321 & 3.6 \\
\hline Woodlands & 2457 & 6.7 \\
\hline Shrublands & 1187 & 3.3 \\
\hline Farm \& settlement & 24246 & 66.6 \\
\hline Grassland/ degraded land & 1278 & 3.5 \\
\hline Riverine trees & 95 & 0.3 \\
\hline Marshland & 5780 & 15.9 \\
\hline Pond & 40 & 0.1 \\
\hline
\end{tabular}

Source: Woldeamlak Bewket (2002).

\section{Resource scarcity and degradation and socioeconomic circumstances of farm households in the Chemoga watershed}

\subsection{Demographic Profile of the Surveyed Households}

Table 4 shows the demographic composition of the sample households. The total population of the 133 households was 834, of which 437 were males and 397 were females. The male population outnumbered the female population giving a sex ratio of $110 \%$. The average household size for the overall households was 6.3 , with a slight variation between the four villages. It was 6.0 in Dangule, 6.2 in Keny, 6.6 in Sinan and 6.3 in Yegagna. But these averages cannot be indicators of the gross fertility levels of the population. By the average household size it was to refer to the number of individuals currently living under one roof; thus excluding children of some households who may have established their own households. Nearly all the households were found to be nucleated families.

The overwhelming majority of the population was young. The population segment under the age of 15 years accounted for $53 \%$ of the total. The number of individuals whose age was above 64 was only two. The working age population, following the conventional categorization, was 389 . The age-dependency ratio was therefore $114.4 \%$ which was composed of $113.9 \%$ young-age dependency and $0.5 \%$ old age ratio. The fact that the majority of the population is young implies that the pressure on the land resource is on the increase. 
Table 4. Demographic composition of the sample households$\mathrm{N}^{\mathrm{o}}$. of individuals by age and sex

\begin{tabular}{|l|l|l|l|l|l|l|l|l|}
\hline \multirow{2}{*}{ Age groups } & \multicolumn{2}{l|}{ Dangule } & \multicolumn{2}{l|}{ Keny } & \multicolumn{2}{l|}{ Sinan } & \multicolumn{2}{l|}{ Yegagna } \\
\cline { 2 - 9 } & male & female & male & female & male & female & male & female \\
\hline $0-14$ & 66 & 43 & 52 & 55 & 51 & 60 & 62 & 54 \\
\hline $15-64$ & 66 & 53 & 48 & 44 & 44 & 48 & 47 & 39 \\
\hline$\geq 65$ & 1 & 0 & 0 & 0 & 0 & 0 & 0 & 1 \\
\hline
\end{tabular}

\subsection{Land holdings}

Land is the basic source of livelihood in rural Ethiopia. Land has been under state ownership since the 1975 national land reform, and there have been many redistributions and readjustments since then, in an attempt to accommodate newly forming households. In the study region (Amhara Regional State), the last readjustment was conducted in 1997 . The frequent redistribution has led to the subdivision of farmlands into ever-smaller parcels. In the sample villages, the average holdings were less than a hectare in Dangule ( $0.97 \mathrm{ha})$ and Sinan $(0.89 \mathrm{ha})$ villages, just over a hectare in Keny (1.18 ha) and about 1.8 ha in Yegagna (Table 5). Taking the average household sizes of the respective villages, per capita holdings were 0.16 ha in Dangule, 0.19 ha in Keny, 0.13 ha in Sinan and 0.29 ha in Yegagna. The inter-village difference in sizes of farmland per household is a result of several factors: total area and nature of terrain of the villages, population sizes and extent of non-utilizable degraded lands in the villages. Also, there was a significant variation in the size of holdings among households. Of the surveyed households, two had more than 2 ha and three had no land at all. In fact, it was learned from informal discussion with farmers that there were a considerable number of households in all the four villages who possessed no piece of land. The pattern was similar to the national level reality. According to CSA (1995), some $80 \%$ of the Ethiopian farmers in the highlands $(>1500 \mathrm{~m})$ cultivate less than 1 ha of farmland. 
Table 5. Household size and land holdings of households$\%$ of respondents

\begin{tabular}{|l|l|l|l|l|}
\hline & Dangule & Keny & Sinan & Yegagna \\
\hline Household size (numb.) & & & & \\
$\leq 3$ & 5.3 & 6.3 & - & - \\
$4-6$ & 57.9 & 50.0 & 45.2 & 59.4 \\
$7-9$ & 34.2 & 40.6 & 51.6 & 40.6 \\
$\geq 10$ & 2.6 & 3.1 & 3.2 & - \\
\hline Total land held (ha) & & & & \\
$\leq 0.5$ & 15.8 & 6.3 & 16.1 & 15.6 \\
$0.6-1.0$ & 55.3 & 50.0 & 74.2 & 43.8 \\
$1.1-1.5$ & 13.2 & 25.0 & 6.5 & 25.0 \\
$1.6-2.0$ & 10.5 & 12.5 & 3.2 & 9.4 \\
$>2.0$ & - & 6.3 & - & 3.1 \\
\hline
\end{tabular}

Source: Field survey

Sharecropping was the main mechanism of gaining access to cropland by the landless. The sharecropping arrangements were between the landless households and those households that lacked the means of cultivation such as oxen, labour or seed, which were often women-headed households or elderly people. According to the commonly accepted sharecropping arrangement, the two parties each took half of the produce from the rented plot. The other means of gaining access to cropland, mainly for newly formed households, was inheritance from parents, which has contributed significantly to land fragmentation. It is however, becoming less important as the size of land available to parents has become very small. Given the increasing rural population, while land is fixed, increasing landlessness will be a critical problem.

Nearly all of the interviewed farmers stated that croplands are becoming scarcer in their communities (95\% of respondents). Some $10 \%$ of the respondents stated that their own holdings decreased by $50 \%$ over the past 10 years, while $6.5 \%$ and $9.7 \%$ indicated that their holdings decreased by 25 and $75 \%$, respectively, over the same period. The decrease in land holdings was attributed to the increased population in the area (73\% of respondents). The farmers were also asked whether their holdings were adequate to support their families and if not, to estimate size of farm that would be sufficient. $85.8 \%$ responded that their holdings were insufficient. Mean desired holdings expressed by the farmers themselves were 1.9 ha in Dangule, 2.0 ha in Keny, 1.7 ha in Sinan and 1.9 ha in Yegagna. Though their holdings were insufficient and many felt that cropland was getting scarcer, the majority stated that they would not like to resettle ( $78.4 \%$ respondents) even if they 
were to be taken to new areas where land might be abundant, because of the bad history of resettlement in the country.

The quality of farmlands varies considerably within villages, and in fact, within farms as well. This is taken into consideration during land redistribution and readjustment activities; i.e., attempt is made to provide equal access to all types of land fertility classes to each household. The result is that farmers operate more than one parcels of land, which can be located long distances apart. The farmers included in the survey operated, on average, 3.3 plots in Dangule, 3.1 plots in Keny, 2.7 plots in Sinan and 3.5 plots in Yegagna. As it is often argued, fragmentation has negative effects on the intensity with which land can be utilized and crops managed. For instance, fragmentation causes croplands to be reduced to narrow corridors running downslope. Such land strips will be inconvenient to apply structural soil and water conservation measures. Moreover, the 'linear' shapes will dictate plowing to be carried out along the slope rather than across, which will significantly increase the magnitude of 'tillage erosion'. Thus, these very small and fragmented holdings are, generally, conducive neither to optimization of agricultural practices nor the application of land management measures. However, in view of the majority of the surveyed farmers the advantages of fragmentation, such as risk distribution and enabling fair access to good quality soils, outweigh the disadvantages ( $86.3 \%$ of respondents).

Household members provided the labour that is needed for the farming operation. The majority of the surveyed households had adequate supply of labor. As it can be seen in Table 5, some 53\% of the households had 4 to 6 members; and some $41 \%$ had 7 to 9 members. On the other side, $56 \%$ of the households possessed only 0.6 to 1.0 ha of farmland. Only $2.3 \%$ of them owned more than 2 ha. More explicitly, the farmers were asked whether labor shortage was a problem in their farming activities. More than $72 \%$ of the respondents asserted that labor supply was not a constraint in their farming operation. According to these farmers, there was, in deed, disguised unemployment of the labor force due to the land shortage.

\subsection{Crop Production}

Crop production is the major source of income to the farmers in the study area. The main crops cultivated are barley (Hordeum vulgare), oats (Avena sativa), horse beans (Vicia faba), and potatoes (Solanum tuberosum) in Dangule village. In the Sinan village wheat (Triticum vulgare) and onion (Allium cepa) are cultivated in addition to those crops cultivated in Dangule. Being at a lower elevation than these two, tef (Eragrostis tef) is cultivated in Keny and Yegagna in addition to those 
crops cultivated in the Sinan village. In Dangule and Sinan, potato is grown twice a year depending on whether sufficient rain falls in a particular year. All other crops are cultivated once in a year.

Table 6 shows estimated incomes of the sample households from crop production at averages prices of bega and kiremt for the year 1998/99. The produces are expressed in monetary equivalents to enable comparisons and better understanding. The average prices for the different crops vary between the seasons. Generally, it is low in the bega season and high in the kiremt season. Barley and oats account for the largest share of the total annual income of households in Dangule (75\% of total) and Sinan (50\% of total), while wheat is the most important source of income in Keny ( $42 \%$ of total incomes), and in Yegagna tef is the most important ( $46 \%$ of total incomes). Farmers grow the different crops as a strategy to averse any risk, to spread out food availability and to adjust for local agroecological conditions.

Table 6. Estimated average incomes of the sample households from crop production (Eth. Birr) in 1998/99 (Eth. Birr 1.00 = US\$ 0.125)

\begin{tabular}{|l|l|l|l|l|l|l|l|}
\hline Dangule & \multicolumn{3}{l|}{ Keny } & Sinan & & Yegagna \\
\hline Crop & Birr & Crop & Birr & Crop & Birr & Crop & Birr \\
\hline Barley/oats & 467 & Barley/oats & 428 & Barley/oats & 379 & Barley/oats & 188 \\
\hline Beans & 52 & Beans & 92 & Beans & 219 & Beans & 22 \\
\hline Potatoes & 107 & Wheat & 521 & Wheat & 65 & Wheat & 336 \\
\hline- & - & Potatoes & 41 & Potatoes & 40 & Potatoes & 49 \\
\hline- & - & Tef & 69 & Onions & 51 & Tef & 571 \\
\hline- & - & Onions & 98 & - & - & Onions & 73 \\
\hline Total & 626 & Total & 1249 & Total & 754 & Total & 1239 \\
\hline
\end{tabular}

When reporting to the survey team, some of the farmers did not distinguish between barley and oats because they considered oats as a type of barley.

The yield per hectare of the different crops varies among the villages, as was learned during the survey. It was generally highest in Yegagna and lowest in Dangule. The farmers in all of the villages also witnessed that productivity of their plots had declined ( $93 \%$ of respondents) over the years, and as a reason for the decline in productivity, 'ageing of the land' was repeatedly mentioned (48\% of respondents). Other reasons given by the farmers included drought ( $26 \%$ of respondents), soil erosion ( $12 \%$ of respondents) and their inability to use chemical fertilizers because of the high cost (24\% of respondents); and some gave other more household-specific reasons. The high cost of fertilizers as a problem was mentioned by the households in Keny and Yegagna, where nearly all of them used the input although at a very low rate of application. In Danglue and Sinan, none of 
the sample households used chemical fertilizers believing that the crops' response to fertilizers was zero due to the cold climates.

\subsection{Livestock tending}

As in all other parts of the Ethiopian highlands, livestock are an integral part of the sedentary life of people in the study area. Table 7 shows the number and types of farm animals kept by the surveyed households. The total number of farm animals of the surveyed households was 873, including cattle, sheep, horses and donkeys. This represents 6.6 farm animals per household. There were also 121 chickens, which is 0.9 per household. The composition of the farm animals was such that cattle accounted for $47.6 \%$, sheep for $38.4 \%$ and horses and donkeys for the balance (14\%). In terms of TLU, the total of farm animals of the surveyed households was about 416, with average holdings of 3.1 TLU per household in Dangule, 2.8 TLU in Keny, 2.9 TLU in Sinan and 3.7 TLU in Yegagna. The number of livestock owned by households was the largest in Yegagna, the downstream village, because of the favorable environmental condition and a relatively more abundant grazing area. Sheep and horses dominate in Dangule and Sinan. In Keny and Yegagna, cattle are as important. Horses and oxen provide the draught power needed for the farming; and sheep and poultry are very important sources of cash and food.

The contribution of livestock as cash sources is significant. For instance, in the year 1998/1999, sales of livestock, livestock products, chickens and eggs contributed to $14 \%$ of the total income of the surveyed households in Dangule and Keny and $20 \%$ in Sinan and Yegagna. Farmers usually sell farm animals to cover bigger expenses like land taxes and other government obligations. The horses and the few donkeys available give the service of locomotives to transport people and goods. They are essential means of transportation. As it is the case for the country at large, given the physiographic irregularity and the indolent economic growth, the significance of equines as a mode of transport appears to remain indispensable for a long time to come.

Livestock are the source of manure that is used as organic fertilizer or for domestic fuel. As estimates indicate, 1 TLU produces 3.2 tons of manure per year (ILCA 1981 quoted by Amare 1981). As per this estimate, livestock of the surveyed households can produce a total of about 1330 tons of manure per annum. This is equivalent to a considerable quantity of chemical fertilizers if used for soil improvement.

As elsewhere in the country, livestock ownership is used as a measure of wealth status of households in the communities studied. That is, livestock 
ownership is the main differentiating factor between the wealthier and poorer households. Thus, there is a social standing attached to the number of livestock owned regardless of the feed shortage. There is a serious shortage of animal feed. In kiremt the livestock are dependent on heavily degraded (overgrazed) communal lands and on some crop residues collected in bega. In bega crop residues are the main feed. Residues of wheat and barley are, however, also used as roof covers, specially in Dangule and Sinan villages, thus sometimes an absolute choice to be made is whether to use the residues as animal feed or as part of own shelter.

According to the farmers, the causes to the shortage of livestock feed are drought (18\% of respondents), human population pressure and expansion of cultivation ( $49 \%$ of respondents) and livestock population pressure and overgrazing (3\% of respondents); and the rest gave various reasons. Also, 34\% of the respondents believed that common property nature of the grazing lands contributed to its degradation and shrinkage in area. On the other hand, $16 \%$ of the respondents firmly expressed that they would not suggest redistribution of the grazing lands amongst community members for privatized use. As a lasting solution to the problem of feed shortage, the farmers suggested increasing of grazing land areas (25\% of respondents), introduction of controlled grazing systems (16\% of respondents) and reduction of livestock numbers $(10 \%$ of respondents). The rest suggested various and different solutions to the problem.

Table 7. Total number of livestock owned by the sample households

\begin{tabular}{|l|l|l|l|l|}
\hline & Dangule & Keny & Sinan & Yegagna \\
\hline Calves & 13 & 8 & 11 & 30 \\
\hline Cows & 23 & 20 & 20 & 42 \\
\hline Heifers & 11 & 4 & 11 & 30 \\
\hline Horses & 41 & 14 & 29 & 14 \\
\hline Oxen & 31 & 42 & 23 & 55 \\
\hline Sheep & 116 & 44 & 66 & 109 \\
\hline Donkeys & - & 10 & - & 14 \\
\hline Young bulls & 7 & 5 & 7 & 23 \\
\hline Poultry & 30 & 25 & 34 & 32 \\
\hline
\end{tabular}

Regarding the trend in livestock numbers, the farmers indicated that there had been an overall increase at the village levels, while per capita holdings had been decreasing. Some $88 \%$ of the respondents stated that their own holdings had decreased, while $8 \%$ indicated that their holdings remained constant and $3 \%$ indicated that it increased. Reasons for the decrease in the number of livestock per 
household, mentioned by the farmers, include drought ( $28 \%$ of respondents), feed shortage ( $48 \%$ of respondents) and others (the balance). $48 \%$ of the respondents further added inadequacy of veterinary services as a problem in their livestock production enterprise. The increase in the overall livestock numbers indicates a growing pressure on the land.

Oxen are the engines of the subsistence crop production activities. Lack of this main resource implies vulnerability of a household to food insecurity. Oxen determine the efficiency of cropping. Hence, oxen ownership among the surveyed households is shown separately in Table 8 . Nearly $22 \%$ of the households did not possess any ox; some $44 \%$ owned only a single ox; $32 \%$ had a pair of oxen and only two households were found to possess 3 oxen. This compares very well to the situation at the national level where some $30 \%$ of highland farmers were found to be without an ox in 1994/95 (CSA 1995). To have no ox or even only one is a serious constraint to farming. The oxless farmers try to overcome this problem and get their pieces of land plowed through several arrangements. These include leasing out of their lands for crop sharing, using ox pairing with others, exchanging human labor for oxen, pairing an ox with a horse and using a pair of horses. In Dangule and Sinan, in particular, horses are the most important means of plowing, either a pair of horses or an ox and a horse paired together.

Table 8. Number of oxen owned per household in the sample villages- $\%$ of respondents

\begin{tabular}{lllll}
\hline No. of oxen & Dangule & Keny & Sinan & Yegagna \\
\hline 0 & 31.6 & 9.4 & 38.7 & 6.3 \\
1 & 55.3 & 50.0 & 48.4 & 21.9 \\
2 & 13.1 & 40.6 & 12.9 & 65.6 \\
3 & - & - & - & 6.3 \\
\hline
\end{tabular}

\subsection{Expenditures}

Table 9 shows items of expenditure and amounts of expenses which were incurred by the sample households in the four villages in the year 1998/99. The largest item of expenditure was for purchase of clothing. Purchase of food items such as salt, edible oil, coffee, sugar and spices, which are not produced by households themselves constituted the second largest item of expenditure in Dangule and Sinan, but the third largest in Keny and Yegagna (preceded by that for purchase of chemical fertilizers). Then, religious festivities, such as the commemoration of days of the Saints and mahber, a social/mutual aid association which involves 
festivities, constituted the third major item of expenditure in Dangule and Sinan, but the fourth in Keny and Yegagna.

Table 9. Items of expenditure and amount of expenses (in Eth Birr) of the sample households in 1998/99 $(1.00=$ US\$ 0.125)

\begin{tabular}{|l|l|l|l|l|}
\hline Items of expenditure & Dangule & Keny & Sinan & Yegagna \\
\hline Clothing & 167 & 204 & 186 & 191 \\
\hline Community contribution & 15 & 9 & 5 & 7 \\
\hline Death-related & 41 & 17 & 35 & 23 \\
\hline Fertilizers & - & 153 & - & 178 \\
\hline Food items & 166 & 121 & 153 & 129 \\
\hline Kerosene & 40 & 28 & 28 & 25 \\
\hline Land use fee & 26 & 27 & 25 & 30 \\
\hline Religious festivities & 84 & 112 & 147 & 88 \\
\hline Schooling children & 11 & 12 & 22 & 13 \\
\hline Seeds & 19 & 16 & 33 & 18 \\
\hline Total & 569 & 699 & 634 & 702 \\
\hline
\end{tabular}

The other important items of expenditure were kerosene for lighting purposes, land use fees, seeds and death-related expenses. There are also wedding-related expenses, depending on whether a household had any member who got married that specific year or not. These were found to be very low during the mentioned year because it was a year hit by drought; hence not included in the list of items of expenditure. The differences between the villages in amounts of total expenditure follow the same pattern as the total incomes.

\subsection{Income-expenditure balances}

Annual income-expenditure balances of the sample households are given in Table 10. Both the income and expenditure figures are as estimated by the households themselves. For the calculation of the annual incomes of the households, five activity categories were identified: crop production, livestock rearing, off-farm works, sales of wood and wood products and remittances. Annual incomes of the households in all the four villages were generally low. Annual incomes from crop production ranged from Eth. Birr 1,249 in Keny to 626 in Dangule (Birr $1.00=$ US\$ 0.125) at average (of bega and kiremt) prices. Incomes from sales of livestock and livestock products including poultry ranged from Eth. Birr 112 in Dangule to Eth. Birr 351 in Yegagna. 
Because of the relative agro-ecological positions, the households in Dangule and Sinan are much poorer than those in Keny and Yegagna. Total annual incomes followed the elevation gradient, decreasing rapidly as elevation increases. This shows the magnitude of influence of the physical environmental factors on the wellbeing of these subsistence farmers. There will be a difference of about Eth. Birr 300 , on average, in annual incomes from crop production comparing the bega and kiremt prices, the higher being at kiremt prices. Farmers will thus get better cash if they could sell their little produce that they would sell in the kiremt season. However, the farmers are required to pay land tax and other governmental and social obligations (e.g. religious festivities) in the bega season, hence they cannot take advantage of the raised market prices of the kiremt season.

Table 10. Income-expenditure balances of the sample households (in Eth Birr) in 1998/99 (1.00= US\$ 0.125)

\begin{tabular}{lllll}
\hline & Dangule & Keny & Sinan & Yegagna \\
\hline Income from crop production" & 626 & 1249 & 754 & 1239 \\
Income from livestock products & 112 & 224 & 216 & 351 \\
Income from off-farm** activities & 0 & 62 & 86 & 64 \\
Income from remittance & 0.4 & 1.9 & 3.2 & 9.4 \\
Income from sale of trees and wood & 41 & 29 & 30 & 29 \\
Total income & 779 & 1566 & 1089 & 1692 \\
Total expenditure & 569 & 699 & 634 & 702 \\
Income-expenditure balance & 210 & 867 & 455 & 990 \\
\hline
\end{tabular}

"Computed at average prices (of bega and kiremt) for each crop.

** There is difference between off-farm activity and non-farm activity. The first includes farming activities outside of one's own farm, whereas the second strictly refers to activities outside of farming.

Incomes from off-farm activities and remittances were scanty. For instance, only $13 \%$ of the surveyed households were engaged in additional off-farm activities, where the definition of off-farm activities included all activities outside of one's own farm: working on another farmer's farm, petty trading, weaving, carpentry, smithing and pottery. Hence, in spite of the fact that land has become scarce and degraded and productivity declined over time, as expressed by the farmers themselves, it seems that the farmers lack (flexibility or) the opportunity to move away from their age-old practices and engage in other income generating activities. This indicates the need for an effective external intervention along this direction so that part of the population will be taken off the land. The other important (third largest) source of income was from sale of wood and wood products. This contributed to $5.3 \%$ of the total income of households in Dangule, 
$1.8 \%$ in Keny, $2.7 \%$ in Sinan and $1.7 \%$ in Yegagna. $18 \%$ of all the households responded that they generated some income by selling trees and fuelwood. Some of them sold trees planted by themselves, but others sold wood from natural woodland areas and forests. The latter is rather a threat to the remaining meager natural vegetation resource in the watershed.

The last row in the table (Table 10) shows the net balance between total annual incomes and expenditures. These income-expenditure balances show the proportion of households' produces that are used for domestic consumption purposes. Indeed, not all reflected by the balance is available for domestic consumption as allotments of crop produces should be set aside for seeds for the next cropping season.

\section{Conclusions}

As is the case in much of rural Ethiopia, the natural resources base is the essential basis of livelihood of the people in the study watershed. Nearly $100 \%$ of incomes of the surveyed households came from their small farms. The people are poor, living on meagre annual incomes ranging from Birr 779 (1.00 Birr 0.125 \$US) in an upstream village (Dangule) to Birr 1692 in a downstream village (Yegagna) per household. Crop production and livestock rearing contributed to more than $93 \%$ of the total annual income of households, and nearly $3 \%$ was secured from sale of trees and wood. Only very few households were found to be engaged in off-farm activities as additional sources of income. This indicates the heavy dependence of the people on the land.

On the other hand, land has become scarce and landholdings per household have been declining because of the increasing population. Moreover, productivity of croplands has declined over time due to 'ageing' of the land (as described by the surveyed households), drought, soil erosion and the farmers' inability to use fertilizers. The scarcity and decline in productivity of croplands has thus contributed to poverty of the farm households. The people are not only povertyridden but also, forced by the necessity for survival, they are agents of destruction of the resources base (to worsen their future).

There has also been a decreasing trend in the number of livestock owned by households, contributing towards poverty of the people. On the other hand, increase in the human population has caused an overall increase in the total livestock population in the communities, creating pressure on grazing lands and shortages of feed. The shortage of feed was identified to be one of the main reasons, the other being drought, for the decline in the number of livestock owned by the households. Heavy grazing removes protective vegetation cover, and leads 
to soil compaction, surface sealing, increased runoff, and consequently soil loss in grazing lands. Not only does it effect clearing of vegetation and the subsequent effects on the grazing lands, but also affects cultivated lands, in much the same way, because free roaming feeding on crop residues takes place after harvesting.

The rural households in the study area are therefore facing problems of poverty and resource degradation, which is also the case in many parts of Ethiopia. Rural poverty and scarcity and degradation of resources are highly intertwined in the country, reinforcing each other in a vicious circle, where people overexploit their resources forced by circumstances, and where they get poorer because the resources are depleting. According to the results of this study, the PPE downward spiral appears to be prevailing in the area. These problems thus require prudently composed solutions that integrate development and conservation measures. In general terms, solutions should include improving productivity of the farming system through technical interventions, creating non-farm employment opportunities to the population and easing human and livestock population pressures on the land. The overall goal should be towards alleviation of rural poverty through conservation-based use of natural resources as resource degradation is recognised to be a 'cause, symptom and result of poverty' (Blaikie 1985). 


\section{REFERENCES}

Alemneh Dejene. 2003. Integrated Natural Resources Management to Enhance Food Security. Environment and Natural Resources Working Paper 16, Rome: FAO.

Amare Getahun. 1981. "Stability and Instability of Mountain Ecosystems with Special Reference to Ethiopia." Mountain Research and Development 4 (1): 39-44.

Azene Bekele. 2001. "Status and Dynamics of Natural Resources in Ethiopia" In Taye Assefa, editor. Food Security through Sustainable Land Use: Population, Environment and Rural Development Issues for Sustainable Livelihoods in Ethiopia, Addis Ababa: NOVIB partners Forum on Sustainable Land Use, 165-184.

Azene Bekele. 1997. "A Participatory Agroforestry Approach for Soil and Water Conservation in Ethiopia." Tropical Resource Management Papers, No. 17, Wageningen: Wageningen Agricultural University.

Bekele Shiferaw and S. Holden. 1999. "Soil Erosion and Smallholders' Conservation Decisions in the Highlands of Ethiopia." World Development 27 (4): 739-752.

Bekele Shiferaw and S. Holden. 1998. "Resource Degradation and Adoption of Land Conservation Technologies in the Ethiopian Highlands: A Case Study in Andit Tid, North Shewa." Agricultural Economics 18: 233-247.

Belay Tegene. 2000. "Processes and Cause of Accelerated Soil Erosion on Cultivated Fields of South Welo, Ethiopia." Eastern Africa Social Science Research Review 16 (1): 1-21.

Berhanu Nega and Seid Nuru. 1999. "Performance of the Ethiopian Economy 19911998." In Alemayehu Geda and Berhanu Nega, editors. The Ethiopian Economy: Performance and Evaluation. Proceedings of the 8th Annual Conference on the Ethiopian Economy, Addis Ababa: Ethiopian Economic Association (EEA), 19-48.

Blaikie, P. 1985. The Political Economy of Soil Erosion in Developing Countries, London: Longman Group Ltd.

Boserup, E. 1965. The Conditions of Agricultural Growth: the Economics of Agrarian Change under Population Pressure. London: Earthscan Publications Boserup, E. 1981. Population and Technological Change. Chicago: University of Chicago Press.

Brown, L. R. 1995. Who Will Feed the Earth: Wake-up Call for a Small Planet? New York: W.W. Norton and Co. 
Bryman, A. and D. Cramer. 2001. Quantitative Data Analysis with SPSS Release 10 for Windows: a Guide for Social Scientists, London: Routledge.

Clay, D. C., Daniel Molla and Debebe Habtewold. 1999. "Food Aid Targeting in Ethiopia: a Study of Who Needs it and Who Gets it." Food Policy 24: 391409.

CSA (Central Statistical Authority). 1995. Agricultural Sample Survey 1994/95 (1987 E.C.), vol. 3. Report on Agricultural Practices (Private Peasant Holdings, Meher Season). Statistical Bulletin No. 132, Addis Ababa: CSA.

Eberstadt, N. 1995. "Population, Food, and Income: Global Trends in the Twentieth Century." In R. Bailey, ed. The True State of the Planet. New York: The Free Press, 7-47.

Ehrlich, P.R. and A. J. Ehrlich. 1990. The Population Explosion. New York: Simon and Schuster.

El-Swaify, S. A. and H. Hurni. 1996. "Transboundary effects of soil erosion and conservation in the Nile basin." Land Husbandry 1 (1\&2): 6-21.

Ermias Bekele. 2003. "Causes and Consequences of Environmental Degradation in Ethiopia." In Gedion Asfaw, ed. Environment and Environmental Change in Ethiopia. Consultation Papers on Environment N0.1. Addis Ababa: Forum for Social Studies, 24-31.

FAO. 1986. Ethiopian Highlands Reclamation Study; Final Report, Rome: FAO.

FAO/UNESCO. 1990. Soil Map of the World: Revised Legend. World Soil Resources Report 60, Rome: FAO.

FDRE (Federal Democratic Republic of Ethiopia). 1997. Environmental Policy, Addis Ababa: Environmental Protection Authority in collaboration with the Ministry of Economic Development and Cooperation.

Gete Zeleke. 2000. Landscape Dynamics and Soil Erosion Process Modelling in the North-western Ethiopian Highlands. African Studies Series A16, Berne: Geographica Bernensia.

Goodland, R. 1992. "The Case that the World has Reached Limits." In R. Goodland, H. Daly and S.El Serafy, eds. Population, Technology and Lifestyle: The Transition to Sustainability. Washington, D.C.: Island Press.

Gozamen Woreda Office of Agriculture. 2001. Annual Report for the Year 2000/2001 (in Amharic; unpublished report, pp. 85), Debre-Markos: Gozamen Woreda Office of Agriculture.

Gracia-Barrios, R. and L. Gracia-Barrios. 1990. "Environmental and Technological Degradation in Peasant Agriculture: A Consequence of Development in Mexico." World Development 18 (11): 1569-85.

Grepperud, S. 1996. "Population Pressure and Land Degradation: The Case of Ethiopia." Journal of Environmental Economics and Management 30: 18-33. 
Hardin, G. 1993. Living Within Limits: Ecology, Economics and Population Taboos. Oxford: Oxford University Press.

Hurni, H 1993. "Land Degradation, Famine and Land Resource Scenarios in Ethiopia." In D. Pimentel, ed. World Soil Erosion and Conservation. Cambridge: Cambridge Univ. Press, 27-62.

Leach, M. and R. Mearns (editors). 1996. The Lie of the Land: Challenging Received Wisdom on the African Environment. London: The International African Institute in association with James Currey Ltd. and Heinemann.

Malthus, T. 1798. An essay on the Principles of Population.

Martine, G. 1996. Population and Environment in the Current Development Scenario. Harvard Centre for Population and Development Studies. Working paper series N0.96.02.

Mazzucato, V. and D. Niemeijer 2000. Rethinking Soil and Water Conservation in a Changing Society: A Case Study in Eastern Burkina Faso. Tropical Resource Management Papers 32, Wageningen: Wageningen University.

Mengistu Woube. 1997. "The Blue Nile River Basin: The Need for New Conservation-based Sustainability Measures." SINET: Ethiopian Journal of Science 20 (1): 115-131.

Mohr, P. A. 1971. The Geology of Ethiopia. Addis Ababa: Haile-Selassie I Univ. Press.

Mulat Demeke. 1999. "The Challenge of Increasing Food Production in Ethiopia." In Alemayehu Geda and Berhanu Nega, eds. The Ethiopian economy: Performance and Evaluation. Proceedings of the 8th Annual Conference on the Ethiopian Economy, Addis Ababa: Ethiopian Economic Association (EEA), 49-72.

Muluneh Woldetsadik. 2003. "Population Growth and Environmental Recovery: More people, More trees; Lesson Learned from .Western Gurageland." Ethiopian Journal of the Social Sciences and Humanities, I (1): 1-33.

Myers, N. and J. Simon. 1994. Scarcity or Abundance: A Debate on the Environment. New York: W.W. Miflin \& Co.

Panayotou, T. 1994. "Population, Environment and Development Nexus." In R. Cassen, ed. Population and Development: Old Debates, New Conclusions. Oxford: Transaction Books.

Panayotou, T. 1993. Green Markets: the Economics of Sustainable Development. San Francisco: Institute for Contemporary Studies Press.

Sahilu Habte. 2003. "Population, Environment and Development." In Gedion Asfaw, ed. Environment and Environmental Change in Ethiopia. Consultation Papers on Environment No.3. Addis Ababa: Forum for Social Studies, 16-22. 
Scherr, S. 2000. "A downward spiral? Research Evidence on the Relationships Between Poverty and Natural Resource Degradation." Food Policy 25 (4): 479-498.

Simon, J. 1981. The Ultimate Resource. Princeton: Princeton University Press.

Simon, J. 1990. Population Matters: People, Resources, Environment, and Immigration. New York: Simon and Schuster.

Sonneveld, B. G. J. S. 2002. Land Under Pressure: The Impact of Water Erosion on Food Production in Ethiopia. Maastricht: Shaker Publishing.

Sutcliffe, J. P. 1993. Economic Assessment of Land Degradation in the Ethiopian Highlands. Addis Ababa: Ministry of Planning and Economic Development.

Tiffen, M., M. Mortimore and F. Gichuki. 1994. More People, Less Erosion: Environmental Recovery in Kenya. Chichester: Wiley and Sons.

TGE (Transitional Government of Ethiopia). 1991. Ethiopia's Economic Policy During the Transitional Period. Addis Ababa: TGE.

TGE (Transitional Government of Ethiopia). 1992. Ethiopia's national report on environment and development: a report prepared for the UN Conference on Environment and Development, Addis Ababa: TGE.

Thornthwaite, C.W. 1948. "An Approach toward a Rational Classification of Climate." Geographic Review, 38:55-94.

UNICEF. 1994. The state of the world's children, 1994. Oxford: Oxford University Press.

Woldeamlak Bewket. 2003. "Household Level Tree Planting and its Implications for Environmental Management in the North-western Highlands of Ethiopia: A Case Study in Chemoga Watershed, Blue Nile basin." Land Degradation \& Development, 14: 377-388.

Woldeamlak Bewket. 2002. "Land cover dynamics since the 1950s in Chemoga watershed, Blue Nile basin, Ethiopia." Mountain Research and Development 22 (3): 263-269.

Woldeamlak Bewket. 2001. "The Need for a Participatory Approach to Soil and Water Conservation (SWC) in the Ethiopian Highlands: A Case Study in Chemoga Watershed, East Gojjam." Eastern Africa Social Science Research Review, 17 (2): 43-68. 